\title{
Calibration of the Reacting Vessel of a Downdraft Gasifier for Temperature Optimization: Initial Validation
}

\author{
Okorie Ngozi.N.*1, Akpambang Victoria.O.E², Agbetoye L.A.S ${ }^{3}$, Okoronkwo Afamuefuna .E. ${ }^{2}$, \\ Adeeyinwo Christina. E. ${ }^{2}$
}

National Agency for Science and Engineering Infrastructure, Center for Excellence in Nanotechnology and Advanced

Materials, Akure, Ondo State, Nigeria ${ }^{1}$

Chemistry Department, Federal University of Technology Akure, Ondo state, Nigeria ${ }^{2}$

Agric Engineering Department, Federal University of Technology Akure, Ondo state, Nigeria ${ }^{3}$

\begin{abstract}
To achieve a tar free syngas production, the design and process variables of a gasifier must be considered and calibrated for optimum performance. This has been a major challenge in most gasification operation establishing the operating temperature with sensors considering the operational environment and duration. The research work presents a simple but valid process for the initial determination and calibration of temperature which can be done for any type of gasifier. This experimental calibration was done to establish the operating conditions of a laboratory scale fixed bed, downdraft gasifier for the conversion of wood waste to gaseous fuel using air as a medium by monitoring product parameters. The temperature, bed material, air flow ratio, nature and composition of the pellets and the product of the operation were considered for various trials. High temperature was achieved by increasing the refractory material used at the reduction zone of the bed and introducing char as bed material thus ensuring that the pyrolytic char is reduced with little or no tar in the product gas.
\end{abstract}

Keywords: Calibration, Downdraft gasifier, Temperature, Operating conditions, waste conversion.

\section{INTRODUCTION}

Gasification is a thermochemical conversion of biomass or other organic mass to a low heating value gas in an oxygen deficient environment. (Balas et al., 2007; Bhavana and sastry, 2011). This process generates renewable energy from biomass feedstock that can stand as an alternative to fossil fuel energy (Sutton et al). Gasification aims at transforming the largest amount of energy contained in the feed fuel (biomass wood waste) into the largest possible amount of energy in a gaseous form (Busa, 2013; Balas et al., 2007). This happens in a series of reaction that occur at an elevated temperature of about $750^{\circ} \mathrm{C}-1000^{\circ} \mathrm{C}$ (Bhavanam Sastry 2011). The conversion of biomass using air as the reacting medium gives a mixture of gases called producer gas. Some of which are combustible [Syngas $\left(\mathrm{CO}, \mathrm{H}_{2}\right.$ and $\left.\left.\mathrm{CH}_{4}\right)\right]$ and some are non - combustible (higher hydrocarbons, tar, $\mathrm{N}_{2}$ and impurities) (Zhon et al., 2015; Bhavanam and Sastry, 2011; Balas et al., 2007). Air is the most commonly used gasification medium both for commercial and laboratory demonstration. These exit gases have an expected volumetric rate of about $50 \% \mathrm{~N}_{2}, 8 \%-20 \% \mathrm{H}_{2}, 8 \%-20 \% \mathrm{CO}$, and $2 \%-4 \% \mathrm{CH}_{4}$ with $\mathrm{CO}_{2}$ and $\mathrm{H}_{2} \mathrm{O}$ as the remaining volume (Akudo et al.,2012).

The design and operation of a gasifier require an understanding of the gasification process, its configuration, size, feedstock, and operating parameters influence on the performance of the plant. Thermo-chemical gasification of biomass is a well-known technology that can be classified depending on the gasifying agent: air, steam, steam-oxygen, air- steam, $\mathrm{O}_{2}$-enriched air, etc. Several types of gasifiers have been studied and developed; these gasifiers have different hydrodynamics (especially the way in which the solid fuel and the gasification agent are contacted), gasification agents (air, oxygen and/or steam) and operating conditions such as temperature and pressure.

The most important types are fixed-bed gasifier, (downdraft gasifier and updraft gasifier operated in counter-current, co-current or cross-current mode), fluidized bed gasifier and entrained flow gasifier. Downdraft gasifiers try to avoid the disadvantage of high tar contents by injecting the gasification agent not at the bottom but to a certain height above the bottom (Fjellerup et al., 2005). The main difference to updraft gasifier is that the gas flows co-currently downwards with the biomass. This leads to an order of the reaction zones from top to bottom with the result of low tar content in the fuel gas, namely, drying, pyrolysis, oxidation, and reduction zone. In any type of gasification operation, the 


\section{International Advanced Research Journal in Science, Engineering and Technology}

Vol. 7, Issue 12, December 2020

\section{DOI 10.17148/IARJSET.2020.71211}

reduction zone is the temperature controlling part of the gasifier type. The general performance and longevity of any gasifier is a function of the temperature of the reduction zone (Jia et al., 2013).

Tar is a major problem in a gasification process that can hinder the effective generation and use of the product gas (Balas et al., 2007; Bhavanam Sastry 2011; Akudo et al.,2012). To achieve a high conversion of the biomass and a low tar content insitu, the operating conditions must be properly selected, bed additives or catalyst can be used and a general gasifier modifications (Devi et., 2003). This can only be obtained by calibration and optimization. The rate determining step in a gasification process is the reaction between the char formed at the pyrolysis stage. The gaseous environment depends largely on variables such as pressure, temperature, particle size, mineral content and porosity. If these parameters are not managed well, more tar will be obtained (Asadullah,2014). Tar is an undesirable aromatic byproduct having condensable hydrocarbon complex polyaromatic hydrocarbon and oxidized $1-5$ aromatic ring. To produce a clean gas by the destruction of these tar component, temperature and other process parameters must be considered ( Basu,2006; Koukouzas et al, 2008; Brandin et al., 2011) The parameters include gasifier type, pressure, bed material, equivalent ratio ER, etc.

Temperature is a critical operating condition that needs to be highly controlled and monitored since it controls gas composition, tar concentration; reaction rate and ash build up (Asadullah, 2014; WIPO,2013). The operating temperature in the gasifier is recommended to be as high as possible $\left(>800^{\circ} \mathrm{C}\right)$ (Bhavanam and Sastry 2011; Basu, 2006). Calibration of the bed temperature will help to ensure that the required temperature is attained. Calibration of the reacting vessel will help to ensure that the optimum conditions required for these process parameters to give a high quality gaseous fuel is attained. For any instrument used for process analysis in the industry, the precision and accuracy of such instrument must be determined so as to give credibility to the response obtained from it especially in a newly constructed and installed instrument. Instrument Calibration is intended to eliminate or reduce bias in the reading over a range for all continuous value (Adeeyinwo et al.,2013). . Determining and establishing the temperature at the reaction zone to be as high as required for the operation will bring an appreciable increase in the product gas / gas yield and heating value. Temperature affects both the amount of tar formed and also the composition of tar since the chemical reactions are temperature dependent. (Bharanam and Sastry, 2011).

One of the key technological challenges limiting the reliability and economics of coal and biomass gasification is the lack of temperature sensors capable of reliably performing in a harsh gasification environment over extended periods of operation (Jia et al., 2013). According to World Intellectual Property Organisational International Bureau (2013), it is an object of invention for an operator to accurately and instantaneously adjust and fine-turn process parameter for the gasification of various materials in a gasifier reactor. Innovative attempts and methods have been described by different researchers on how to determine and validate the temperature in a gasifier especially at the reduction zone. Most of these methods are secondary measurements that are relatively easy to obtain such as temperatures, pressures, and compositions of streams into and out of a gasifier can be used in conjunction with empirical or theoretical models and correlations to estimate inaccessible operating parameters inside the reaction zone.

New methods of obtaining direct measurements of gasification temperature using methods that do not require the direct insertion of a fragile sensing element into the harsh environment is gradually taking over (WIPO, 2013). The most widely used techniques in this category are optical measurements, including combustion specific measurements of temperatures and reaction composition with minimally invasive (require a transparent access port) which is a function of the type of gasifier and the field of research. Jia et al., (2013) described a non-invasive ultrasound approach for temperature measurement in a gasifier reacting vessel.

This work describes and presents an initial validation of a simple method requiring minimal access port of a thermocouple and a monitoring of product stream as we adjust and fine-turn other process parameters in a non slagging gasifier to calibrate the gasifier and ensure high temperature for an optimum generation of the product gas with high combustible content.

\subsection{Chemistry of Gasification}

Several reactions occur in a downdraft gasifier. These reactions occur in zones as solid and gases move forward in the same direction (Koukouzas et al, 2008) and at different temperature. Basically, when biomass undergo thermochemical conversion in an oxygen deficient environment, the reaction starts with drying in a drying zone at a temperature of about $150^{\circ} \mathrm{C}-300^{\circ} \mathrm{C}$, producing water vapour. This is followed by the pyrolysis zone where the biomass is pyrolysed at a temperature of about $300^{\circ} \mathrm{C}$ to $500^{\circ} \mathrm{C}$ to give char, tar and a mixture of gases Eqn (1) .

Biomass $\longrightarrow$ Char + tar and gases $\left(\mathrm{CO}_{2}, \mathrm{CO}, \mathrm{H}_{2} \mathrm{O} . \mathrm{H}_{2}, \mathrm{CH}_{4}, \mathrm{CnHn}\right)$------ Eqn (1) 


\section{International Advanced Research Journal in Science, Engineering and Technology}

Vol. 7, Issue 12, December 2020

\section{DOI 10.17148/IARJSET.2020.71211}

Combustion reaction of the pyrolysis product occurs in the oxidation (combustion) zone producing secondary reaction and heat needed to carry out the whole process.

$$
\begin{array}{ll}
\mathrm{C}+\mathrm{O}_{2} & \longrightarrow \mathrm{CO}_{2} \quad \Delta \mathrm{H}=-408 \mathrm{KJ} / \mathrm{mol} \\
2 \mathrm{C}+\mathrm{O}_{2} & 2 \mathrm{CO} \longrightarrow \mathrm{H}=-246 \mathrm{KJ} / \mathrm{mol}
\end{array}
$$

These secondary reaction of the pyrolysis and oxidation gases pass through to the reduction zone where actual gasification occurs. Here there is a reduction of the pyrolytic char and a temperature of about $700{ }^{\circ} \mathrm{C}-1000{ }^{\circ} \mathrm{C}$. The end product of the chemical reactions that take place in the reduction zone is a combustible gas which can be used as fuel gas.

This gives room for reduction in tar production (<100mg/Nn) (Bala et al., 2007, Basu, 2013 / 2018). Most of the heat produced is used up at this zone. If the residence time in the hot zone is too short or the temperature too low, then medium sized molecules can escape and will condense as tars and oils, in the low temperature parts of the system.

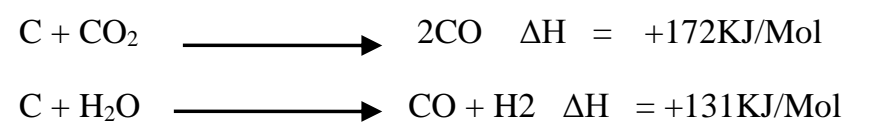

\section{EXPERIMENTAL MATERIALS METHODS}

Biomass wood waste (sawdust) collected from sawmills within Akure metropolis, Ondo State, Nigeria were pelletized and used for the calibration of the gasifier. Sawdust was discovered as the most abundant wood waste type in most sawmills within and around Akure which require useful conversion from waste to wealth. These samples were initially dried, sorted into particle sizes using a sieve shaker. To achieve uniform temperature and better heat transfer in the particles lower size of $600 \mu \mathrm{m}$ retained was selected for further work (Cao et al., 2008; Malik et al.,2015). The sample were made into pellets having a shape factor of 2.7 (Biswas and Umeki, 2005; Garcia- Maraver and Carpio, 2015).The samples were characterized prior to pelletisation and the basic physiochemical properties that can affect the process was determined. This led to the introduction of binder in the pellet production. The moisture content was determined to meet the required optimum of $10-15 \%$ as stated by most research to reduce the energy that will be lost in the gasifier during drying. (Aashish and Sumeet, 2016). The result of the physicochemical characterization has been reported (manuscript under review).

\subsection{Experimental Set up}

A fixed bed downdraft gasifier designed and constructed in - house was calibrated for the biomass gasification process. The schematic diagram is shown in Figure 1. The installation is composed of the following parts ; biomass feeding system, air pump, gasification reactor vessel (drying zone, oxidation, pyrolysis zone, reduction zone, air inlet nozzle called tuyree, gas/solid outlet, ash discharge tray); a flaring unit; cyclone attached to a sample bottle, a free sample bottle; a filter, a pump, outlet port and gas detection set up. (gas cell, water trophy, absorption bottles). Temperature monitoring unit. These parts are arranged in modules for easy of adjustment and adaptation

The gasification vessel is a furnace system having a throated constriction supported in a cylindrical vessel. The reduction zone lagged with fibre glass as the refractive material to ensure high temperature and high reduction of char at this zone. It has one air inlet tuyree opening through the air pump to atmospheric pressure. A grate attached at the bottom of the chamber provides support for the bio- fuel. A type $\mathrm{K}$ thermocouple was attached to the reduction zone of the system. The feeding system is attached to the top of the chamber. A discharge tray is attached at the bottom of the chamber to collect solid residue. 


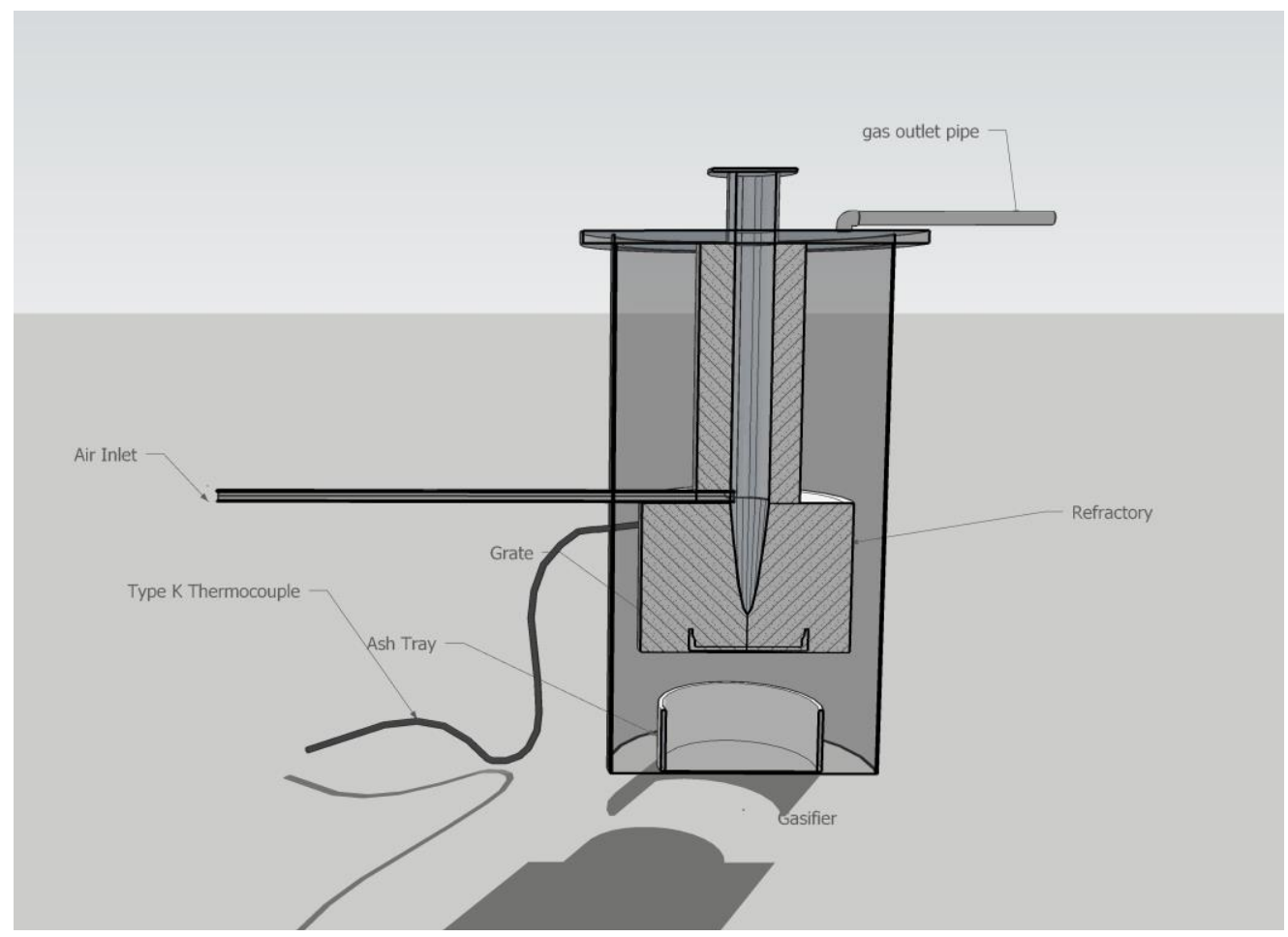

Figure 1. : Gasification reaction vessel

\subsection{Experimental Method}

The initial operation trials were done with air as gasification agent supplied by an air pump of $130 \mathrm{~W}$ capacity with a flow rate of approximately $9.16 \times 10^{-6} \mathrm{~m}^{3} / \mathrm{h}$ introduced through a side tuyree which was left at a maximum and the feed inlet was left open at a maximum such that the equivalent ratio $\mathrm{ER}=1(100 \%)$. The temperature of the reacting vessel and the process was monitored and calibrated using a type $\mathrm{K}$ thermocouple. The thermocouple was calibrated using standard chemicals of known melting point before the various trial tests began (Cao et al., 2008; Igboanugo, 2003). The feedstock was further dried after the initial operations with some system adjustments.

The system adjustments were made with an increase in the fiber glass at the reduction zone for proper refractory; a reduction in the air flow ratio at the inlet and an opening of the feed inlet; an introduction of char from the previous run as a bed material. For each stage, the temperature of the system was monitored and the content of the sample bottles observed and the ash discharge system monitored. These trials were repeated severally to ensure that the operating conditions needed to achieve optimum conversion to combustible gas products is achieved.

\section{RESULTS AND OBSERVATIONS}

The result of the initial calibration of the thermocouple presented in Table 1 showed that the thermocouple is good and ready for use in the gasification process. The result of the temperature calibration process is presented in Table 2- 4 . Gasification process is influenced by a number of variables which include particle size, moisture content and chemical composition of the wood type such as ash content (feed stock variables). This was observed from the large water vapour that was present in the sample bottle at the initial stage that led to further drying of the feed sawdust pellets. The process variables like temperature, air ratio, pressure, bed material (Link et al., 2013) was also observed and adjusted in the process. As the inlet air was given $100 \%$ complete opening such that equivalent ratio $E R=1$, temperature increased and combustion was at a maximum and short resident time was observed but slagging and large ash deposit was observed. This showed that the melting point of ash was also gotten and this is not helpful in the gasification process (Bhavanam and Sastry, 2011).

The sample bottles had large deposits of tar, oil and water vapour (Plate1) after the first few trials. This confirms that conversion and optimum conditions have not been achieved. When there are non-pyrolyzed fuel, hydrocarbons (tar) will be evolved which have a condensation temperature of $200-500^{\circ} \mathrm{C}$ when wood is gasified (Fjellerup et al., 2005) as was shown by the thermocouple reading. When the bed material (refractory lining and char from previous run as catalyst) was increased at the char reduction zone, temperature of the reacting vessel was increased and the air tuyree regulated to be about $1 / 3$ such that the air flow ratio was reduced. The resident time was also regulated and an obvious 
Vol. 7, Issue 12, December 2020

DOI 10.17148/IARJSET.2020.71211

temperature ramping was observed, the tar component of the gas was reduced drastically with no slagging as witnessed by clear sample bottles Plate 2. (Zhon et al., 2015; Caraccio et al., 2014). The water vapour was also reduced. The type $\mathrm{k}$ thermocouple confirmed that the temperature of the vessel went as high as $780^{\circ} \mathrm{C}$ and above.

The thermocouple reading was dragging and was not rising steadily as the temperature got to $600{ }^{\circ} \mathrm{C}$ and above. A pyrometer is recommended for such high temperature operation and reading (Jia et al., 2013; WIPO, 2013). The relatively clear sample bottles confirm that the prevalent temperature of the gasification reaction vessel is above the condensation temperature of tar. In the work of Fjellerup et al., (2005), downdraft gasifier at this stage nearly elimates these compounds except for a trace of compound with $\mathrm{m} / \mathrm{z} 60$ and the tertiary aromatics are now predominant: benzene (78), naphthalene (128), phenanthrene (178) and pyrene (202). Tertiary alkyl aromatics are also present: toluene (92), indene (116); and further some phenol (94). The composition of the tar was not considered at this stage bearing in mind that the aim of the calibration was to ensure temperature optimization. Further work will on the elimination of these compounds using downstream secondary methods to further improve the quality of the gaseous fuel.

Table 1. Calibration of the thermocouple

\begin{tabular}{llll}
\hline Standard Chemicals & Melting point $\left({ }^{\circ} \mathbf{C}\right)$ & $\begin{array}{l}\text { Type k Thermocouple } \\
\left({ }^{\circ} \mathbf{C}\right)\end{array}$ & Observations \\
\hline Environment & 28 & 28 & Warm Day \\
Benzoic Acid & 128 & 128 & White powder turned clear \\
Solder (alloy of Pb \& Sn) & 430 & 423 & Melted \\
Zinc granules & 500 & 500 & Melted into ashes \\
Melting Point glass & $560-570$ & 560 & Bent \\
Magnesium ribbon & 651 & 648 & Deflagrated with a blinding \\
Impure black lead (iv) oxide & 720 & 700 & $\begin{array}{l}\text { Turned yellow Lead (ii) } \\
\text { oxide }\end{array}$ \\
Silver coil & 960 & 780 &
\end{tabular}

Table 2. Calibration of the Reacting Vessel $-1^{\text {st }}$ Trial Test

\begin{tabular}{lll}
\hline Operational Parameters & $\begin{array}{l}\text { Thermocouple } \\
\text { Reading }\end{array}$ & Observation \\
\hline $\begin{array}{l}\text { Equvalent ratio ER }=1 \\
\text { Particle Size }=\mathrm{x} \leq 600 \mu \mathrm{mm}\end{array}$ & Water vapour \\
Refractory Material (fiber glass) - low & 250 & $\begin{array}{l}\text { Dark flowing slag } \\
\text { Deposit of tar through the stream }\end{array}$ \\
Bed Material (char/ ash) - None & 300 & Sample bottles completely dark \\
$\%$ moisture content (dry basis) $10.85 \%$ & 450 & \\
Ash content of feed $-1.93 \pm$ & 480 & \\
Resident time - Short & 520 & Wall temperature increased \\
Tar deposit - Much & 600 & \\
Slagging - Yes & 650 & \\
Combustion rate - High & 600 & \\
\hline
\end{tabular}




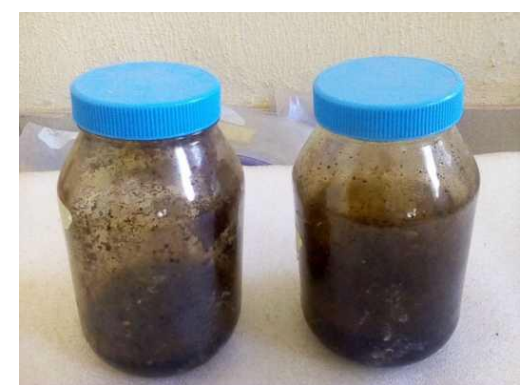

Plate 2: Sample bottles containing large deposit of Tar at temperatures below $500^{\circ} \mathrm{C}$

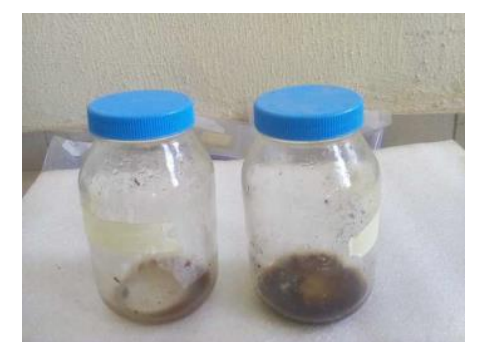

Plate 3: Sample bottles at temperature between $5^{500} \mathrm{C}$ and above.

Table 3. Calibration of the Reacting Vessel $\quad-2^{\text {nd }}$ Trial Test

\begin{tabular}{lll}
\hline Operational Parameters & $\begin{array}{l}\text { Thermocouple } \\
\text { Reading }\end{array}$ & Observation \\
\hline Equivalent ratio ER $=2 / 3$ & 28 & Warm day \\
Particle Size $=\mathrm{x} \leq 600 \boldsymbol{\mu m}$ & 128 & Water vapour \\
Refractory Material (fiber glass) - Increased & 350 & Cloud of smoke / water vapour \\
Bed Material (char/ ash) - Low & 400 & Dark fluid deposits on the bottle \\
$\%$ moisture content (dry basis) $-10.85 \%$ & 460 & Dark tar deposit \\
Ash content of feed - & 500 & Water / oil deposit \\
Resident time $-\quad$ longer & 580 & Hot flue gas \\
Combustion rate $-\quad$ reduced & 600 & Hot flame / \\
\hline
\end{tabular}

Table 4. Calibration of the Reacting Vessel --- $3^{\text {rd }}$ Trial Test

\begin{tabular}{|c|c|c|}
\hline Operational Parameters & $\begin{array}{l}\text { Thermocouple } \\
\text { Reading }\end{array}$ & Observation \\
\hline Air flow ratio $E R=1 / 3(0.3)$ & 29 & Clear \\
\hline Particle size $=\mathrm{x} \leq 600 \mu \mathrm{m}$ & 200 & Cloud of fumes \\
\hline Refractory Material (fiber glass) - Increased & 380 & Steam/ Water vapour on walls surface \\
\hline Bed Material (char/ ash) - Increased & 500 & Clear surface \& golden fluid \\
\hline$\%$ moisture content (dry basis) $-10.85 \%$ & 600 & Golden fluid /red hot flame in the chamber \\
\hline $\begin{array}{l}\text { Ash content of feed }- \\
\text { Further drying of feed at } 120^{\circ} \mathrm{C}\end{array}$ & 680 & $\begin{array}{l}\text { Hot gas /very hot flame /thermocouple } \\
\text { reading not moving as before }\end{array}$ \\
\hline Resident time - longer & 680 & Glowing flame at flaring unit \\
\hline Combustion rate - reduced & 600 & Glowing flame at flaring unit \\
\hline
\end{tabular}

\section{CONCLUSION}

Experimental temperature calibration of the reaction vessel and the monitoring of the other operational parameters such as the air flow ratio, pellet nature and composition, reaction time, residue on sample bottles and ash discharge tray by adjusting and has helped in achieving standard operating conditions for obtaining a tar-free combustible gas in-situ. Large deposit of tar and slag was observed at temperatures below $500^{\circ} \mathrm{C}$. At temperatures above $600^{\circ} \mathrm{C}$ little or no tar was observed. This implies that pyrolysis of wood char at temperatures above $600{ }^{\circ} \mathrm{C}$ did not result in further release of tar compounds from the char as was also confirmed by (Fjellerup et al., 2005). This will help to achieve high level of conversion of raw material to gas. A thermocouple is better used for low temperature operations, a pyrometer is recommended for such high temperature operations. This work presents a simple but valid experimental process for the determination and calibration of temperature in any fixed bed gasifier. 


\section{International Advanced Research Journal in Science, Engineering and Technology}

Vol. 7, Issue 12, December 2020

DOI 10.17148/IARJSET.2020.71211

\section{REFERENCES}

1. Aashinsh D and Sumeet S (2016), Temperature Behaviour and Performance of Briquettes in Gasifier using Sawdust as raw Materials, International Journal of Computer Applications (0975-8887) pg (32-37).

2. Adeeyinwo C.E., Okorie N.N., Idowu G.O. (2013). Basic Calibration of UV/Visible Spectrophotometer. International Journal of Science and Technology. (2)3: 247-251

3. Akudo C O., Terigar B.G and Theegala C.S. (2012), Lowering Gasifier Tars and Particulates Using Heated Dolomite Catalyst and a Particulate Filter. Smart Grid and Renewable Energy 3: 56-61. (http:// www.sciRP.org/ journal/sgre)

4. Asadullah Mohammad (2014), Barriers of commercial Power using biomass gasification gas: A review Renewable and Sustainable Energy Reviews 29,(201-215).

5. Balas M., Lisy M., and Moskaki J. (2007). Biomass Gasification: Gas for cogeneration unit International Journal of Energy and Environment Issue 4,(1).

6. Basu Prabir (2006). Combustion and Gasification in Fluidized Beds, CRC press Taylor and Francis Group, Ration London NewYork. ISBN: O -8473 -3396 -2 books.google.com.ng

7. Basu P., (2013), "Biomass Gasification, Pyrolysis, and Torrefaction, Practical Design and Theory" Second Edition Elsevier Inc.

8. Brandin J, Tunrer M. and Odenbrand I. (2011), Small Scale Gasification: Gas Engineer CHP for Biofuels Linnaeus University, ISBN: 978 - 91 86983 - 07- 9 .

9. Bhavanam and Sastry (2011), "Biomass Gasification Process in Downdraft Fixed Bed Reactor: A Review , International Journal of Chemical Engineering and Application. Vol. 2, No. 6, pg 425-433.

10. Cao Y., Gao Z., Jin J., Zhou H., Zhao H., Liu h. (2008) Synthesis Gas Production with an Adjustable H2 / CO Ratio through the Coal Gasification Process: Effects of Coal Ranks and Methane Addition. Energy and Fuels (22):1720 - 1730

11. Devi L., Ptansinski K., and Janssen F., (2003) A Review of the Primary Measures for Tar Elimination in Biomass Gasification Processes. Biomass and Bioenergy 249 (2): 125-140. DOI:10.1016/SO961-9534(02)00102-2.

12. Dimitar karakashev and Yifeng Zhang (2019) Bio Energy and Bio Chemicals Product from Biomass and Residual Resources. book. gcoogle. com.ng

13. Gracia-Maraver A. and Carpio M., (2015) Factors Affecting Pellet Quality. WIT Transaction on State of the Art in Science and Engineering, (85) WIT press. www.intpress.com doi:10.2495/978-1-84566-062-8/002.

14. Fjellerup J., Ahrenfeldt J.,Henriksen U., and Gobel U., (2005), Formation,Decompostision and Cracking of Biomass Tars in Gasification. Technical University of Denmark Department of Mechanical Engineering . ISBN nr.:87-7475-326-6

15. Igboanugo N.N (2003) Design and Operation of an In-house Crucible Furnace for the Production of Glass at Different Eutectics. A Thesis Submitted for the Award of PGD in Industrial Chemistry. Department of Chemistry, Federal University of Technology Akure, Nigeria.

16. Jia Y., Puga M., Butterfield A., Christensen D., Whitty K., and Mikhail Skliar (2013) Uitrasound Measurements of Temperature Profile across Gasifier Refractories: Method and Initial Validation. Energy Fuels 27, 4270-4277.dx.dio.org/10.1021/ef3021206.

17. Koukouzas N., Flueraru C., Katsiadakis A., Karlopoulos E. (2008) Fixed Bed Gasification of Biomass Fuel: Experimental Results. Energy for Sustainable Future. ISBN 978-963-9696-38-9

18. Link S., Kask U., Paist A., Siirde., Arvelakis S., Hupa M., Yrjas P, and Kulasts I. (2013) Reed as a Gasification Fuel: a Comparison with Woody Fuels Mires and Peat (13)4: 1-12 http://www.Mires - and - peat.net/ISSN 1819 -754 x @ 2013 International Mire Conservation Group and International Peat Society.

19. Malik B., Pirzadah T.B., Islam S.T., Kumar M., Rehman R.U. (2015) Biomass Pellet Technology: A Green Approach for Sustainable Development. Springer International Publishing Switzerland Agricultural Biomass Potential Material: 403-433. DOI: 10.1007/978-3-31913847-3-19.

20. World Intellectual Property Organisation International Bureau (2013).Temperature Measurement in a Gasification Reactor. WO2013/174969AI. Patentimages.storage. googleapis.com/25/21/27/8d5c6b2fde7964/WO2013174969AI.Pdf.

21. Zhon B., Zhou J., Zhang Q., Chen D., Liu X., Wang L., Ji R. and Ma H. (2015) Moulded solid fuel particles BioResources 10(4), 7795-7807. 